\title{
Should Forest Transition Theory include effects on Forest Fires? The case of Spain in the second half of the Twentieth Century
}

\begin{abstract}
This paper analyses the increase in forest surface covered by trees in Spain in the second half of the twentieth century in the light of Forest Transition Theory and explores the existence of a statistical relationship between this process and the extension of forest fires. The study describes the afforestation policy based on new forest plantations started by Franco's regime in 1940 which surpassed the chronological limits of the dictatorship and lasted until 1988, linking it to the forest fires that occurred in the period 1968-2002. The objective is to determine, at a provincial level, the extent to which the afforestation activity affected the number of hectares burnt. The evidence shows a significant positive relationship between forest fires and the afforested hectares, especially 30-35 years after plantations. The effect increases when the model is implemented exclusively for the Cantabrian and Atlantic north-west provinces, especially affected by afforestation programmes. Our findings reinforce the need to complement certain models of Forest Transition based on tree plantations, taking into account the possible relationship that they have with fires, particularly in environmental contexts prone to fires.
\end{abstract}

Keywords: Forest fires; afforestation; forest history; environmental history; panel data. JEL Codes: C22, N54, Q23, Q28 


\section{Introduction}

Since its formulation in the 1990s, the concept of Forest Transition (FT) and its consideration as a Theory (the Forest Transition Theory -FTT) has generated a vast body of literature and much controversy (Mather, 1992; Grainger, 1995; Mather and Needle, 1998, Perz, 2007; Barbier et al, 2010; Nunez-Mir et al, 2015). The first version of FTT seeks to describe and explain the reversal of forest cover change trends, from long-term deforestation to stable or increasing forest cover in some countries, explaining it as a process linked to economic and social development (Mather 1992 and 2001). Based on the original version, some studies try to explain FT by the increase in GDP per capita, suggesting the existence of an inverted $U$ shape curve between economic growth and deforestation, that is, the existence of an Environmental Kuznets Curve for deforestation (Barbier and Burguess, 2001), although the evidence for this claim is far from being conclusive (Culas, 2012). Other versions explain FT in a more complex manner, including several variables influencing the evolution of forest surface. The increase in agricultural productivity enabling the concentration of food production on the more productive lands freeing up space for forest; the increase in the demand for forest products and prices which incentivizes forestation processes; the development of State policies promoting forest recovery; or the effects of globalization on the trade of forest products lowering pressures on some forests, are the main variables considered (Rudel et al, 2005; Lambin and Meyfroidt, 2010; Meyfroidt et al, 2013). On the other hand, although most of the research seeking to measure FT has considered only forest surface, the type of forest resulting from the transition could be of prime importance. An FT based on the reforestation of primary or secondary forests could be very different from an FT based on afforestation with tree plantation (Perz, 2007). In this regard, studies have been conducted that attempt to measure the environmental effects of tree plantations on biodiversity, water reserves, flood control or carbon sequestration (Kauppi et al, 2006; Bremen and Farley, 2010; Meyfroidt and Lambin, 2011; Heilmayr, 2014; Pirard, Dal Secco and Warman, 2016). But the effects of FT on forest fires have barely been considered by the literature. Only for the case of Portugal has a relationship between FT and wildfires been considered with the suggestion that fires might be reversing FT in some areas of the country (Mather and Pereira, 2006; Oliveira et al, 2017). In the case of Spain, some studies have also pointed to a direct relationship between FT based on tree plantation and forest fires, which is worth exploring.

The evolution of forest surface in Spain in the second half of the twentieth century could be explained by some of the postulates of FTT. After a secular process of deforestation proved at least for the nineteenth century and the first decades of the twentieth century (Iriarte-Goñi, 2013), forest surface covered by trees started to grow from the middle of the century. Available data for the whole country suggest that the forest surface covered 12.000 hectares in 1950 and 16.000 in 2000, increasing by 33\% (Infante et al, 2014) ${ }^{\mathrm{i}}$. Although the FT process has not been studied in depth, the causes of this growth seem to coincide with some of the postulates of the FTT. The growth of agricultural 
productivity, the intense rural exodus and the increase in the trade of forest products (particularly the trade of timber to produce pulpwood for paper) during the period, suggest that the main means described for FT, according to Rudel at al. (2005) and Lambin and Meyfroidt (2010) could have worked in Spain. But in parallel to those factors, the most directly related cause of the increase in forest surface covered by trees was, undoubtedly, State afforestation policy. Beginning in the 1940s, just after the end of the Spanish civil war, the Forest Administration of the Franco regime started an intense afforestation policy which, surpassing the chronological limits of the dictatorship, lasted until the end of the 1980s and affected more than 3.5 million hectares of forests. Although in some cases afforestation had a protective component related to the management of the basins and rivers and to soil protection (Gomez Mendoza and Mata Olmo, 1992), the main objective of the programmes was to increase the production and large-scale exploitation of timber (Rico, 2008a; 2008b) and to protect the large reservoirs which were being built in order to extend the irrigated areas and increase the production of electricity (Iriarte-Goñi, 2017). The increase in forest surface covered by trees between the 1940s and the 1980s was based on tree plantation programmes which were developed through an authoritarian top-bottom policy, with no consideration of the needs and interests of the people living on the land. From an environmental point of view, plantation was carried out with resinous trees (mostly pines) and in some cases eucalyptus which were planted in large areas covered by a single species, creating woodlands of poor ecological status in terms of age structure, diversity and maturity, fostering the spread of tree diseases, pests and other forest problems (Prieto, 1989; García Abril, 1989; Chauvalier, 1990; Rico, 1995 and 2008a y 208b; Cervera et al, 2016).

It is within this framework that some studies claim that the characteristics of the afforestation model developed in Spain by the dictatorship aggravated the problem of fires and could have been a contributing factor to their increased prevalence (Prieto, 1989; Cabana 2007; Seijo, 2009, Guijarro et al, 2017). To understand the scope of the problem is worth noting that forest fires have constituted one of the main environmental problems in Spain since the second half of the twentieth century. Official statistics collecting forest fire data from 1968 to 2014 reveal that 7.1 million hectares of woodland (trees and scrubs) and pastures have been burnt (more than 150,000 hectares per year as a mean). In this period, fires affected more than $25 \%$ of the total forest area calculated for the country in the third National Forest Inventory (IFN3, 2006). To date, the relationships between afforestation programmes and forest fires have only been described as a possibility, and there are no studies that statistically link these two phenomena. But this possibility opens up a new front in the study and assessment of Forest Transition that is worth exploring, particularly in environmental contexts susceptible to fires.

So, the objective of this study is to explore the existence of statistical linkages between afforestation in the period 1940-1988 and forest fires that occurred in the period 1968 2002 , in order to determine the extent to which the afforestation activity affected the 
number of hectares burnt in the country on a provincial level. It should be noted from the outset that this paper does not seek to offer a complete view of the causality of forest fires, but simply to combine some of the variables that the literature has considered as important in this causality, introducing afforestation as another variable, in order to assess the specific effect that this may have had. In other words, our objective is not to explain the causes of the forest fires, but to analyse the role that afforestation could have had played in them. This information could be an important element in assessing the effects of some model of forest transition.

After this introduction, section two addresses the essential issues of the problem; Section three presents the data used and the model. The fourth section presents the main results which are discussed in section five. Some conclusions are drawn in the final section.

\section{Approaching the problem}

Forest fires are a very difficult problem to analyse on all levels, as assessing their causality is a complex task (Montiel Molina, 2013; Viedma et al, 2015; Vilar et al, 2016). They can be started by natural causes unrelated to human activity or caused by mere negligence or accidents. They can be due to economic and social causes related to land use, natural resource management, activities developed in the forests and the interests associated to all of them (Martínez-Fernandez et al, 2009 and 2013). They can even be caused by problems that are not environmental, economic or social (for example, in the case of random fires started by arsonists suffering from a mental illness). In order to start clarifying this complexity, we can separate the generic causes of forest fires into two different categories, differentiating between the ignition causes and the causes affecting the severity and extension of the fire.

Starting with the ignition causes, the studies addressing this aspect all indicate that the majority of fires are started by humans. According to a study published by the FAO (2007), the "number of naturally occurring fires is small in comparison with those caused by people". The studies analysing the Spanish case can be divided into those that attribute $96 \%$ of fires to human action (Prieto, 1989; Vilar et al, 2016) and those that attribute $70 \%$ to humans, although this second group observes that $20 \%$ of fires have unknown causes (Seijo, 2005). The majority of fires caused by human action in Spain seem to be due to agricultural burning. Fire has traditionally formed part of farm management practices such as stubble burning in order to fertilise the following crop with the ashes or the burning of scrubland in order to create temporary pasture land. In many areas, these practices are still used and other factors, (such as rural depopulation or the ageing of agricultural assets), may lead to an easier loss of control of the fires, causing the destruction of adjacent forest areas. On the other hand, some forest fires are caused by fortuitous accidents related to factors such as the amount of tourists visiting the forests or the proximity and density of the infrastructure (roads, railway tracks or electrical power lines) that runs through them. Similarly, the "agriculture-forest" and 
"urban-forest" interfaces may give rise to more accidental fires (Badía et al, 2011; Viedma et al, 2015). Finally, there are other types of fire that can be divided into those due to individual causes (arsonists) and those caused by different types of social conflict related to the ownership of the forests or the types of use that the different social and economic sectors wish to give to them (e.g., reclassification of land for building, recreational uses, farming and forestry uses, etc. -Fuentes Santos et al, 2013). There have also been cases in which there is a perverse relationship between the increase in the costs and infrastructure related to the extinguishing of the fires (the "Economy of Fire") and the incidence of fires. In this respect, some authors defend the existence of "a growing number of fires set intentionally to obtain temporary jobs in firefighting services" (Chas Amil, 2007).

With regard to the factors that may exacerbate the fires, the technical reports refer to three groups of causes, namely the terrain, the weather and the greater or lesser fuel accumulation within the forests (Martínez Ruiz, 2013). The former two are related to natural causes that are difficult to control. A rugged terrain with many ravines and gorges or with steep hillsides can accelerate the spread of fire and make it more difficult to extinguish (Nunes, 2012). Furthermore, high temperatures, low rainfall or intense, fast winds with low levels of humidity can facilitate the spread of fires (Westerling et al, 2006). The third element relating to forest fuel accumulation also has a natural component linked to the growth capacity of the biomass in different environmental contexts, but is mainly linked to socioeconomic aspects as it depends, to a high degree, on the type of land uses developed in the rural areas.

Several socioeconomic causes can be referred to in order to explain forest fuel accumulation. One of them is the abandonment of traditional farming practices, derived, in turn from the modernisation of agriculture, the rural exodus and the depopulation of the countryside. Within this context, the disappearance of extensive grazing and the discontinuance of the removal of timber, firewood and other forest products have given rise to the proliferation of abandoned forests where a spontaneous reforestation of mainly scrub, together with grass, leaves and dead wood fallen from trees (necromass), generates an accumulation of highly inflammable biomass (Vélez, 2016). Another possible form of biomass accumulation may arise from the opposite circumstance, namely the artificial planting of woodland. In this case, the planting of large areas with just one species of tree may be conducive to the spread of fires, particularly if the species chosen are pyrophytes which have a high flammability index (high incidence of fire risk). In general terms, changes in land use and land cover resulting in the decrease of the variety of plant species has been identified as one of major factors of fire occurrence (Viedma et al, 2015; Vilar et al, 2016)

In the Spanish case, as mentioned above, some studies have directly related the forestry policy developed between the 1940s and 1980s with the increase in the number of fires occurring as from the end of the 1960s. The relationships between the two processes are as follows. First, the policy of large-scale afforestation projects, which was 
implemented during Franco's dictatorship, favoured afforestation with conifers, mainly pine tree that covered more that $80 \%$ of the total afforested area in the period considered here (Vadell et al, 2016b). Furthermore, certain species of fast-growing conifers which represented a high fire risk were preferred (Prieto, 1989). In particular, the pinaster, halepensis and radiata pine tree species which have a flammability index of between 6 and 7 out of 10 were used on $49.8 \%$ of the afforested land between 1940 and 1970, and continued to be used on over $40 \%$ of the land until the end of the 1980s (Vadell, 2016b). On the other hand, both the afforestation using these species and the actions using other species (mainly silvestrys pine and eucalyptus), were carried out through the creation of large single-species masses, which reduced the diversity of the forests, constituting an important factor for the spread of the fires (Vega-García and Chuvieco, 2006; cervera et al, 2016, Guijarro et al., 2017). These afforestation activities were mainly carried out within the political framework of the Franco dictatorship and were therefore imposed with no option for social debates regarding their usefulness or the consequences for the rural population affected. At the same time, from the 1950s, the forestry administration did not incorporate the traditional use of fire as an agricultural management technique in its policies, but implemented campaigns in which any type of fire was considered as negative and was clearly criminalised and prosecuted (Seijo, 2005; Montiel Molina, 2013). All of this may have given rise to increased discontent among the rural population with respect to the forestry administration and its policies and generated a hidden unrest which was manifested through forest fires as a form of resistance and protest (Cabana, 2007; Seijo, 2009). On the other hand, and going beyond fires caused by this conflict, agricultural burning continued to be used, although clandestinely, and this may have increased the risk in case of accident, due to the delay in the actions of the fire extinguishing services who were not warned of the possible dangers. The lower human presence in the woodlands due to the rural depopulation and the increase in the average age of the farmers could also have been contributing factors (MartínezFernández et al, 2009)

In short, the existence of a causal relationship between afforestation and forest fires has been suggested by many studies, but these ideas have been expressed in qualitative terms. There are no studies that have attempted to measure a possible statistical relationship between these variables. Therefore, the objective of this study is to analyse forest fires on a provincial scale in the period 1968-2002, in order to determine the extent to which these fires were related to the afforestation activity which was carried out, also on a provincial scale, in the period 1940-1988. The information available regarding the ignition causes is not sufficiently complete so as to be able to draw conclusions, so this study does not refer to them. It focuses solely on some of the factors that could affect the area that the fires burnt each year, seeking to assess the extent of the influence of afforestation actions.

3. Data and methods 
To develop our work we have collected data on afforestation, forest fires and other control variables for all of the provinces of Spain except for Álava and Navarra, as the data provided by the statistics in both cases are partial. This is probably due to the fact that the forestry administrations of these two provinces have traditionally been highly autonomous in terms of management and statistics compilation. In fact, in both cases, the national forestry statistics have only calculated the forest fires in those forests of Álava and Navarra which, during the majority of the twentieth century, were owned by the State, and represented a very small part of the forest area of the two territories.

The data referring to afforestation actions have been obtained from the forestry statistics for the period between 1940 and 1988, which include data on the afforested area each year in each province. The start date was selected as it was the first year that the Plan General de Repoblación (General Spanish Afforestation Plan), approved in 1939, was executed. For the first few years, the actions were given quite a high level of propaganda, as the afforestation process in the 1940s was conducted on a small scale, but was used as a symbolic image of the construction of a new Spain and the wages that it generated provided an example of the capacity of the new state to give employment to the rural population. From the beginning of the 1950s, however, the process became systematised, and for several years covered areas of almost 120,000 hectares each year and then stabilised at around 100,000 hectares during the 1960s and early 1970s. After the fall of the dictatorship in 1975, the afforestation actions became more irregular and from the beginning of the 1980s they displayed a clear downward trend, but the objectives of the programmes continued to be the same as before. Only at the end of the eighties, new criteria on socioeconomic afforestation objectives were implemented (Rojas, 1987) and the transfer of the majority of the forestry agencies to new regional governments, led to the disappearance of the way in which afforestation had been used in the previous decades. From then, afforestation, related mostly to European policies, was mainly carried out by individual initiatives, with different dynamics in terms of the way it was carried out and the species planted (Vadell, et al, 2016a). For the purpose of our study we have not considered the afforestation activities implemented after 1988 as their effects on forest fires were very different (see Figure 1).

Figure 1.

Afforested area and Burnt Forest Area

( has.) Spain, 1940-2002.

The afforestations were distributed across the provinces according to different criteria that not always are easy to determine. High forest productivity, due to environmental conditions, was the main reason for afforestation in the north-west and south Atlantic provinces, which explains the concentration of programmes in those areas. In other cases, the selection may have been made in accordance with the need to prevent soil erosion on the banks of the newly-built reservoirs (Iriarte-Goñi, 2017) or the degree of 
deterioration of the pre-existing woodland area (Gómez Mendoza and Mata Olmo, 1992). On the other hand, part of the afforestation (around $23 \%$ of the total) was carried out after the prior purchase of the woodlands by the State Forest Heritage and therefore the availability of land for purchase could be an important factor in the distribution of some of the operations (Pemán, 2009). Nevertheless, the rest of the programmes were developed through agreements with local governments called consortiums, which were usually imposed through authoritarian methods. It is worth notting that some consortiums were signed with private forest owners, leaving the forest control in the hands of the Forest administration in exchange for future timber exploitation revenues.

The information that has been published only allows us to differentiate the total area on a provincial level and for the moment we are unable to analyse the information on smaller geographical scales. Neither is it possible to break down the specific species used in the afforestation each year by province as the data are only available on a national scale (Vadell et al, 2016a and 2016b).

Figure 2.

Provincial distribution of Afforested area (1940-1988) and Burnt Forest Area (1968-2002)

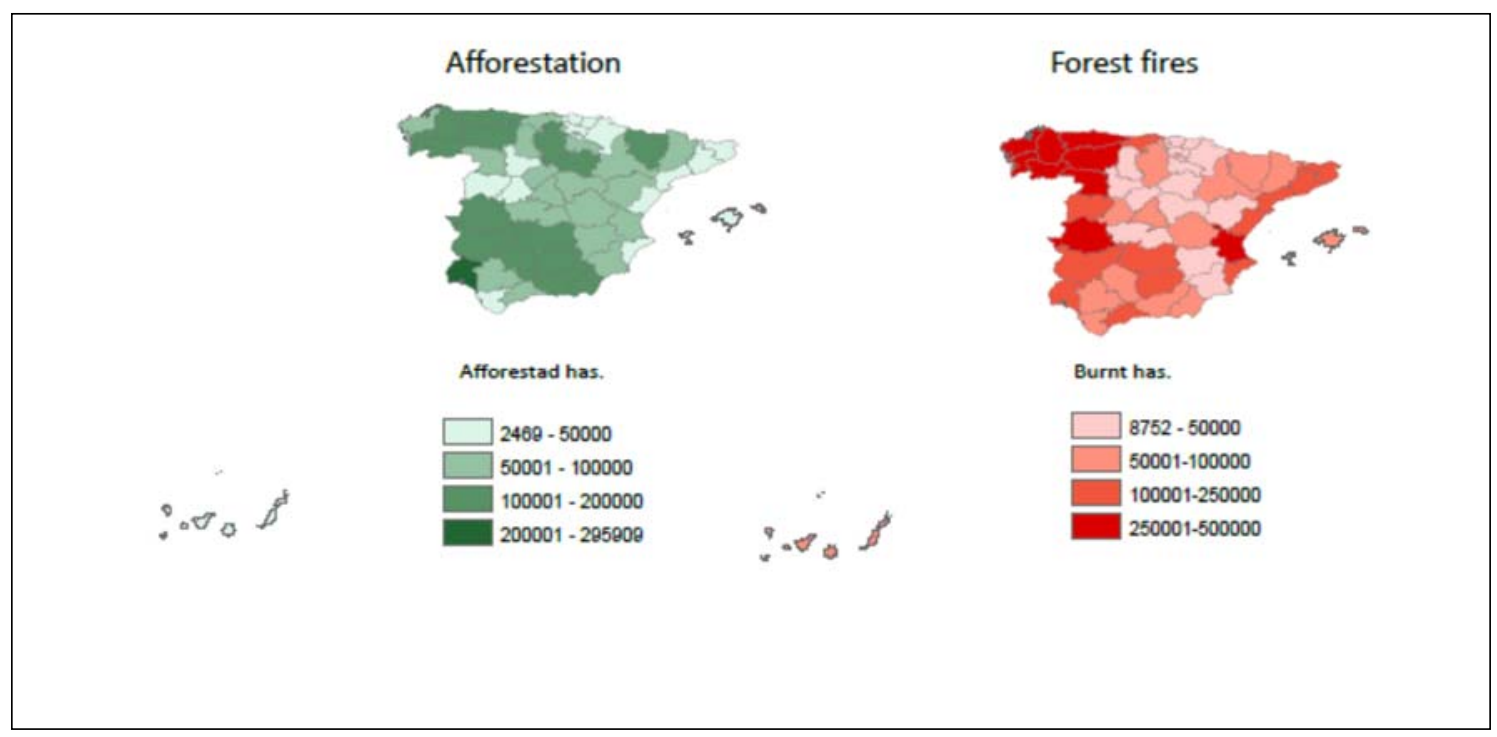

The statistics on forest fires in Spain began to be compiled in 1968. This information includes the individual reports created for each fire throughout the year, with detailed information about the location, duration, possible causes and its effects on several differentiated levels (SGAM, 2012). For our case, the most relevant information to fulfil the objective is the area affected. We have taken this information and aggregated it on a provincial level for each of the years analysed. Therefore, our variable, burnt forest area (BFA), is represented by the forest area in hectares that is burnt each year in each of the Spanish provinces. 
We chose to use the total forest area burnt instead of only the forest area covered by trees burnt for two basic reasons. First, the criteria for calculating the burnt tree-covered area have varied over the years and it may have been underestimated until at least 1987, as only the forest area that was subject to commercial timber use was considered as such (Prieto,1989). Second, there is nothing to suggest that the effects generated by afforestation affect only the area covered by trees. On the contrary, there is a high possibility that the fire can spread to scrubland and pastureland. Within the variable of burnt forest area, the statistic distinguishes between different types of forest ownership, disaggregating the fires occurring in the different types of public forest and private land. Taking into account that most of the afforestation actions implemented until the 1980s were carried out in public areas (belonging to the national or local governments), there was a possibility of using only the public area as a variable. However, there is nothing to suggest that the effects of an afforestation of public land could not extend to adjacent privately-owned woodlands, so we will consider both public and private burnt forest area.

Until the mid 1970s, the BFA remained at below 100,000 hectares per year, but subsequently and for more than two decades it increased considerably with an annual average of 250,000 hectares with peaks which at different moments exceeded 400,000 hectares. From the mid 1990s, the area of forest fires reduced but still remained at an average annual level of around 100,000 hectares (see Figure 1). In total, six million hectares were burnt between 1968 and 2002, that is, 1.5 times the afforested area between 1940 and 1988. Although the forest fires affected all of the provinces to a greater or lesser degree, considering the period as a whole, it may be observed that the areas that were most affected by the forest fires were those in the north-west part of the Iberian peninsula (see Figure 2).

If we summarise the data we can see that both the afforestation and the fires had a different impact in the north-Atlantic area than the rest of Spain. Figure 3 includes the information of the 10 provinces located on the Cantabrian Coast and northern Atlantic coast and the three neighbouring inland provinces with similar forestry features ${ }^{\mathrm{ii}}$.

Figure 3. Percentage of Afforestations and Burnt Forest Area (BFA) in North Atlantic Provinces. Spain 1940-2002. 


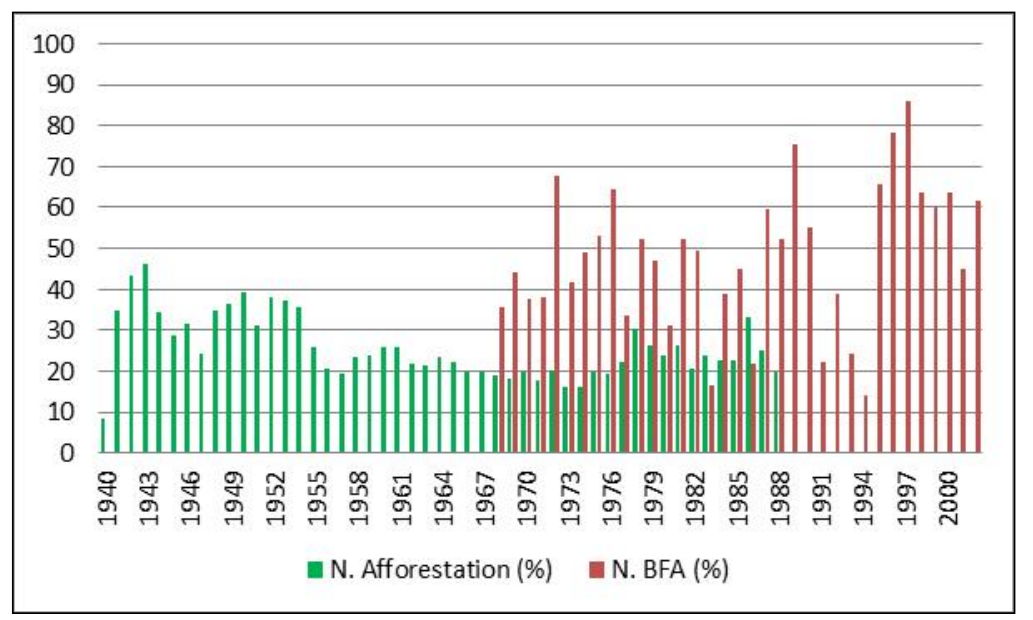

On average, these provinces represented between $21 \%$ and $22 \%$ of the total forest area of Spain, but the figure shows that the incidence of afforestation and fires in them does not always coincide with these percentages. In the first phase of the afforestation process (between 1940 and 1955), the actions carried out in these provinces accounted for over 30\%, and in the final period that we have calculated (from 1976) the percentages were higher than the $20 \%$ that would have corresponded to these provinces according to the forest area. But the discrepancy is much higher in the case of the forest fires, which, on average, represented almost half (47\%) of total fires in all of the years calculated and in certain years they represented over $60 \%$. Based on these data, this study has developed two models: one which includes the afforestation and the forest fires in all of the provinces and another which includes only the 10 provinces of the north-northwest.

One of the main problems when establishing possible relationships between afforestation and fires resides in determining the number of years after which the afforested areas constitute a real fire risk. Everything suggests that the risk of fire in replanted areas grows over time. In the early years of afforestation, the low accumulation of biomass and probably the surveillance activity undertaken by the forestry administration to ensure that the plants have taken root correctly would make the fire risk very low. However, with the passing of time, the maturing of the masses and the relaxation of the surveillance and conservation measures would have considerably increased the fire risk. From this perspective, one possibility would be to consider the afforested area from the plantation year to the fire year assuming a continuous and not uninterrupted biomass accumulation that raises the risk of fire. The problem is that we are not certain that all of the area afforested in a specific year has remained the same until the moment of the fire. On the other hand, the possibility that part of the afforestation carried out in each province did not mature or disappeared before the fires cannot be ruled out.

Due to the lack of certainty regarding the degree of real survival of the afforestation derived from these considerations, we have assumed that the forest fires could have occurred around 30 years after plantation. That is, after a time period had elapsed that 
was sufficient for the trees that had been planted to mature. In fact, as some studies point out (Vignote and Martinez, 1985; Alvarez, 2000), the felling age of most of the pine species used in the afforestation was between 25 and 30 years. Given that this period of time is approximate and there is uncertainty regarding what happened in each case, our model contemplates three possibilities. A possible time lapse between plantations and fires of between 20 and 25 years (A_20-25); another time lapse of between 25 and 30 years (A_25-30) and a third delay of between 30 and 35 (A_30-35). For the three cases we have calculated the average afforested area in hectares in each province during the five years considered. With these three variables we cover a broad period so as to try to establish possible relationships between the date of plantation and the date of the forest fire, but without assuming that in all cases there was necessarily a constant and accumulative process of biomass accumulation from the beginning of plantation which, as we have already seen, cannot be controlled with the available information.

Our model also uses several control variables related to the extension of forest fires. Those discussed by the literature focus mainly on the changes of the use of the land derived largely from the abandonment of agricultural areas and closely linked, therefore, to the modernisation of the economy, the transformations of the rural environment and migrations from the countryside to the towns. In order to analyse these effects, our model includes three complementary variables which are; the evolution of the forest area minus the afforestation (Non-Afforested Forest Area-NAFA); the change in agricultural active population (AAPC), and the evolution of firewood extractions (FWE) for each province. In the case of non-afforested forest areas NAFA, measured in hectares, the model seeks to capture the growth that the forest area has undergone due to causes other than artificial afforestation controlled by Forest administration. These include possible private afforestation outside the consortiums (not compiled in forest inventories before the 1980s) and, most probably, spontaneous forestation processes linked to the abandonment of crops and the reduction in extensive grazing. The reconstruction of the forest area on a provincial scale has been carried out using the forestry statistics of the 1950s and linking the figures of each province with those of the three national forestry inventories (IFN1, IFN2 and IFN3), conducted at the end of the 1960s, the mid-1990s and in the period 2006-2008, respectively. It would be expected that the evolution of the forest area has a positive relationship with the fires, inasmuch as it represents an accumulation of biomass which, especially in the case of abandoned forests, can influence the extension of the burnt hectares.

Information about the AAPC at a provincial level has been extracted from the database of the Instituto Nacional de Estadística (INEbase) and the historical series published by the Banco Bilbao Vizcaya (BBV, 1999). The percentage difference between the agricultural active population of the year and that of the beginning of the period under study has been used. As the decrease in the AAPC is a proxy for the decline in traditional agricultural activities, its relationship with forest fires is considered to be negative. Data regarding firewood extraction (FEW) have been obtained from the 
forestry statistics, which offer annual information about this variable on a provincial scale. In this case it is also considered that the effect is inverse to that of fires, in a dual sense. First, the lower firewood extraction could be interpreted as a further sign of the abandonment of the traditional uses of the forests from which resources are no longer extracted. Furthermore, the reduction in firewood extractions represents a direct increase in the biomass which accumulates in the forest and can negatively affect the severity and extension of the fires.

Our model also introduces some environmental variables which enable us to capture the effects of the annual variations in climate on the incidence of fires. The variables chosen are the annual maximum temperature (TMX) for each province and the frequency of wet days throughout the year (WET). In both cases, the information has been directly drawn from the Climate Research Unit TS 2.1 database, collected by Goerlich (2012) for Spanish historical data. In the case of the TMX variable, a positive relationship is expected and for the WET variable a negative relationship is expected, as the highest maximum temperatures and the lowest frequency of days with probability of rain generate dryness in the atmosphere which can facilitate the spread of the burnt area once a fire has started.

The estimates have been made from the year 1968 (first year for which the forest fires statistics standardised for Spain are available) until the year 2002 (the year from when we can access the rest of the complementary variables). As mentioned above, the afforestation variable is used for the period 1940-1988 applying the previously mentioned time lapses.

Therefore, in order to measure whether afforestation has influenced the burnt forest area in Spain, we have used a fixed effects model (FE) assuming that some time-invariant characteristics of the provinces may affect the dependent variable which we want to control. FE removes the effect of the time-invariant characteristics from the independent variable, so we can assess the net effect of our independent variables. The first model is:

$$
\begin{aligned}
& B F A_{i t}=\beta_{1}+\beta_{2} N A F A_{i t}+\beta_{3} A_{-} 20-25_{i t}+\beta_{4} A_{-} 25-30_{i t}+\beta_{5} A_{-} 20-35_{i t}+ \\
& +\beta_{6} F W E_{i t}+\beta_{7} T M X_{i t}+\beta_{8} W E T_{i t}+\beta_{9} A A P C_{i t}+u_{i t} \quad i=1,2, \ldots N ; t=1968, \ldots, 2002
\end{aligned}
$$

There is a balanced panel with 1,645 observations (47 provinces and 35 years) for the model. Given the differences detected in the north Atlantic area with respect to the rest of the country, this model has also been estimated considering only the ten provinces in this area.

\section{Results}

Table 1 shows the results of the estimation of the model indicated in expression (1) for the 47 Spanish provinces. First, we estimated the fixed effects model with year dummies. These dummies were jointly significant. We used the Modified Wald test to 
check groupwise heteroskedasticity in the fixed effects models (Green, 1997) and the Wooldridge test for autocorrelation (Wooldridge, 2002). Both tests reject the hypotheses of homoskedasticity and non-autocorrelation respectively. We also performed the Breusch-Pagan LM test for cross-sectional correlation (Breusch-Pagan, 1980 ) and the null hypothesis of independence is also rejected for commonly used levels of significance.

In order to estimate the models in the presence of autocorrelation within panels and autocorrelation and heteroscedasticity across panels, we have used the feasible generalised least squares estimates, (GLS) and the panel-corrected standard error (PCSE) estimates, both of them assuming heteroskedasticity (each panel has its own variance) and contemporaneous correlation across the panels (each pair of panels has its own covariance). So, in Table 1 we have distinguished between gls and pcse, and we have also distinguished, between ar1, when we assume that there is $\operatorname{AR}(1)$ autocorrelation within panels, and that the coefficient of the AR(1) process is common to all the provinces, and psar 1 when there is AR(1) autocorrelation and it is assumed that the coefficient of the $\mathrm{AR}(1)$ process is specific to each province.

Table 1: Panel data with all the provinces, except Alava and Navarra

\begin{tabular}{|c|c|c|c|c|}
\hline VARIABLES & $\begin{array}{c}(1) \\
\text { gls_ar1 }\end{array}$ & $\begin{array}{c}\text { (2) } \\
\text { gls } \_ \text {psar1 }\end{array}$ & $\begin{array}{c}(3) \\
\text { pcse_ar1 }\end{array}$ & $\begin{array}{c}\text { (4) } \\
\text { pcse psar1 }\end{array}$ \\
\hline NAFA & $\begin{array}{c}0.00586 \\
(0.00581)\end{array}$ & $\begin{array}{c}0.00775 \\
(0.00616)\end{array}$ & $\begin{array}{c}0.00586 \\
(0.00510)\end{array}$ & $\begin{array}{c}0.00775 \\
(0.00551)\end{array}$ \\
\hline A_20-25 & $\begin{array}{c}-0.0588 \\
(0.151)\end{array}$ & $\begin{array}{c}-0.00532 \\
(0.153)\end{array}$ & $\begin{array}{c}-0.0588 \\
(0.145)\end{array}$ & $\begin{array}{c}-0.00532 \\
(0.148)\end{array}$ \\
\hline A_25-30 & $\begin{array}{c}0.0530 \\
(0.147)\end{array}$ & $\begin{array}{c}0.0750 \\
(0.147)\end{array}$ & $\begin{array}{l}0.0530 \\
(0.194)\end{array}$ & $\begin{array}{l}0.0750 \\
(0.209)\end{array}$ \\
\hline A_30-35 & $\begin{array}{c}0.466 * * * \\
(0.181)\end{array}$ & $\begin{array}{c}0.593 * * * \\
(0.177)\end{array}$ & $\begin{array}{l}0.466^{*} \\
(0.270)\end{array}$ & $\begin{array}{c}0.593 * * \\
(0.286)\end{array}$ \\
\hline FWE & $\begin{array}{c}-1,046^{* * *} \\
(387.5)\end{array}$ & $\begin{array}{c}-1,100 * * * \\
(363.7)\end{array}$ & $\begin{array}{l}-1,046 \\
(989.6)\end{array}$ & $\begin{array}{l}-1,100 \\
(912.9)\end{array}$ \\
\hline TMX & $\begin{array}{c}401.6^{* *} \\
(200.8)\end{array}$ & $\begin{array}{c}376.6^{*} \\
(196.1)\end{array}$ & $\begin{array}{c}401.6 \\
(391.3)\end{array}$ & $\begin{array}{c}376.6 \\
(379.1)\end{array}$ \\
\hline WET & $\begin{array}{c}-822.3^{* * *} \\
(192.4)\end{array}$ & $\begin{array}{c}-851.2^{* * *} \\
(189.1)\end{array}$ & $\begin{array}{c}-822.3 * * \\
(386.0)\end{array}$ & $\begin{array}{c}-851.2 * * \\
(378.4)\end{array}$ \\
\hline AAPC & $\begin{array}{c}-36.28^{*} \\
(19.49)\end{array}$ & $\begin{array}{c}-45.46^{* *} \\
(18.56)\end{array}$ & $\begin{array}{c}-36.28 * * \\
(18.31)\end{array}$ & $\begin{array}{c}-45.46 * * * \\
(17.61)\end{array}$ \\
\hline Constant & $\begin{array}{l}-11,315 \\
(7,873)\end{array}$ & $\begin{array}{r}-12,863 \\
(7,896)\end{array}$ & & $\begin{array}{c}-5,687 \\
(15,052)\end{array}$ \\
\hline Observations & 1,645 & 1,645 & 1,645 & 1,645 \\
\hline R-squared & & & 0.386 & 0.415 \\
\hline Number of id & 47 & 47 & 47 & 47 \\
\hline
\end{tabular}


Our variables of interest, the average hectares of forest planted between 20 and 25, 25 and 30 and 30 and 35 years ago, A_20-25, A_25-30 and A_30-35, respectively affect the number of burnt hectares differently. Irrespective of the method of estimation, GLS or PCSE, and of the assumption made about the autocorrelation, in all cases the average afforestation carried out between 25 and 35 years beforehand has a significance of at least $10 \%$. The rest of the control variables used have the expected sign and are almost always significant.

Given that both the afforestation and the forest fires had a different incidence in the north-Atlantic area than in the rest of the country, Table 2 shows the estimates of the same model but for the ten northern provinces. As for the model with all the Spanish provinces, the Breusch-Pagan LM test for cross-sectional correlation rejects the null hypotheses of independence, but the Modified Wald test for groupwise heteroscedasticity and the Wooldridge test for autocorrelation do not reject the hypotheses of homoskedasticity and non-autocorrelation, respectively. Therefore, for the GLS and PCSE estimates we have used an independent autocorrelated structure, gls_i and pcse_i, because the model does not present temporal correlation. However as it presents cross-sectional correlation, the standard errors are estimated under this assumption.

Table 2: Panel data with Northern provinces.

\begin{tabular}{lcc}
\hline & $(1)$ & $(2)$ \\
VARIABLES & gls_i & pcse_i \\
\hline \multirow{2}{*}{ NAFA } & $0.131^{* * *}$ & $0.131^{* * *}$ \\
& $(0.0375)$ & $(0.0545)$ \\
A_20-25 & 0.336 & 0.336 \\
& $(0.438)$ & $(0.449)$ \\
A_25-30 & $0.576^{*}$ & 0.576 \\
& $(0.313)$ & $(0.392)$ \\
A_30-35 & $\mathbf{1 . 0 0 9 * * *}$ & $\mathbf{1 . 0 0 9 * *}$ \\
& $\mathbf{( 0 . 3 4 9 )}$ & $\mathbf{( 0 . 4 8 6 )}$ \\
ESF & -686.4 & -686.4 \\
& $(510.8)$ & $(675.5)$ \\
TMAX & 25.26 & 25.26 \\
& $(656.1)$ & $(886.5)$ \\
FRHUM & $-2,035^{* * *}$ & $-2,035^{*}$ \\
& $(724.8)$ & $(1,121)$ \\
AAPC & $-79.68^{*}$ & $-79.68^{*}$ \\
& $(40.82)$ & $(42.76)$ \\
Constant & $-30,731$ & $-66,633$ \\
& $(25,023)$ & $(45,958)$ \\
Observations & 350 & 350 \\
R-squared & & 0.655 \\
Number of id & 10 & 10 \\
\hline
\end{tabular}


Standard errors in parentheses. The coefficients with $*, * *$ and $* * *$ are significant at 10,5 and $1 \%$, respectively. The time dummies have not been included in the table.

For these northern provinces, the coefficient of our variables of interest, A_20-25, A_25-30 and A_30-35, are all positive and the latter is highly significant. In addition, the size of the estimator is much larger, approximately twice that of the model for the whole of Spain. The rest of the variables also have the expected sign, and in this case the non-afforested forest area, NAFA, is significant, which is not the case in the model with all the provinces.

\section{Discussion}

In view of the results included in the tables, we can say that, in general terms, the hypothesis assuming that afforestation has aggravated forest fires can be confirmed. A positive and statistically significant relationship can be considered to exist between the afforestation carried out in the period 1940-1988 and the forest fires that occurred in the period 1968-2002. Obviously, this relationship has not arisen immediately after afforestation but with a delay of around 25 years. In the case of all of the provinces, the effect arises with a delay of 25-30 years, but is much greater and highly significant in the following period 30-35 years after the plantation. In the northern provinces, the effect appears earlier (in the period 20-25 years after plantation the effect is positive although not significant) and is also reinforced as time progresses being significant after the time lapse A_30-35. This time lapse period fits quite well with the age of maturity of pine trees, which, as previously mentioned, covered more than $80 \%$ of the afforested area. This does not mean that afforestation can be systematically considered as a principal cause of forest fires, but simply that more hectares were burnt annually in those provinces where more afforested forest area were planted 25-35 years before the fires occurred. Otherwise, both for the whole of the country and for the provinces in the north, all of the control variables have the expected sign. This means that our model is correctly capturing how forest fires have been affected by environmental factors (more fires in the those years with higher maximum temperatures and with fewer wet days) and the relative abandonment of the uses of woodlands (the number of fires has increased as the agricultural population has decreased and also with the decrease in the use of forest measured in firewood extracts).

This result suggests that, in some circumstances, FT has been directly related to forest fires, something that the FTT literature has not considered in depth to date. This idea invites us to explore and discuss which specific characteristics of the Spanish FT affect the size of the areas of forest surface burnt. For this objective we can refer to the type of plantation chosen in afforestation programmes, the economic criteria driving them, and also the political framework within which they were developed.

The relationship between forest fires and afforestation may respond, as indicated in the literature, to the high degree of flammability of the species used to replant and the type 
of plantation mostly chosen (large areas, single-species). Recently a more significant incidence of wildfires on Spanish afforested areas respect to natural forests have been stated for the period 1974-2010, with speciall incidence in the areas afforested with pinus sylvestrys and pinus pinaster (Guijarro et al, 2017). The reasons for choosing these species for afforestation have been the object of much debate. The argument used during the Franco regime and that some still defend is that pines were an appropriate afforestation species due to their frugality (capacity to survive on soils with a low level of nutrients) and their xerophilia (the capacity to adapt to situations of acute water stress) (Ximenez de Embún and Ceballos, 1939; Gil and Prada, 1993; Gil 2008). Pines also constituted the first step in the ecological succession towards higher levels which could consolidate over time (Gil and Prada, 1993). In contrast, the most critical views defend that the choice of species and mono-specific masses responded principally to economic criteria related to economic profitability which, for the national industries, could have meant the choice of fast-growing species, planted economically and which could be exploited in short periods of time in terms of forest economics, (García Abril et al, 1989; Rico, 1995). In support of the strength of these economic criteria, some studies have shown that in certain cases, the planting of fast-growing species was done after the previous uprooting of the autochthonous leafy thickets (Rico, 2008a and $2008 \mathrm{~b}$ ). The critics claim that the afforestation strategy that was followed generated low-quality plantations which led to a reduction in biodiversity and an increase in the probability of being attacked by pathogenic factors such as plagues and fire (Preito, 1989). Our study, which highlights the relationship between afforestation actions and burnt hectares, corroborates this criticism.

The positive and highly significant relationship in the period between 30 and 35 years before the afforestation would indicate that the fires mainly affected those afforested areas once the trees had reached maturity. The causes for this delay between planting and the forest fires could be due to the growth of the inflammable biomass. This possibility gains strength in the case where maintenance and surveillance services in the afforested areas were scarce, as this abandonment would raise the possibilities of fire over time. Another hypothesis is that there may have been some kind of relationship between forest fires and the timber market. As mentioned above, it should be take into account that the felling age of the pine species used in the afforestation was between 25 and 30 years (Vignote and Martinez, 1985) and that the occurrence of fires just before the trees reached this age could affect the markets. The arguments used in this respect are that a large part of the wood extracted from the burnt forests could end up in the shredded wood markets (the most important in the case of Spain), although it did so at a lower price than wood that had not been burnt ${ }^{\mathrm{iii}}$. If this happened on a sufficiently large scale, it could have suppressed the prices of wood in the medium to long term, which would be beneficial for the consuming companies of this raw material, particularly wood pulp factories and paper mills (Fernández Leiceaga, 1990). In any event, these effects could be confirmed by relating the occurrence of fires with the prices of wood over the long term and analysing whether a relationship exists between the two variables. 
The results with respect to the provinces in the north of Spain corroborate the special incidence of afforestation in the burnt hectares of these areas. The explanation given by the literature on forest fires for this area is not related to environmental causes (the Cantabrian and north-east area of Spain is the most humid of the peninsula and the one which records the lowest average temperatures; in other words, the area with weather conditions that are least conducive to forest fires), but socioeconomic causes. On the one hand, Cantabrian and the north-western region is the part of Spain in which forests has traditionally been most integrated with agro-pastoral activities, constituting land for temporary crops, fertilisation elements and livestock fodder (Soto, 2006). On the other hand, it is the area that has the highest forest productivity, and consequently where there was a greater interest to implement the new afforestation model in terms of its most economic aspect of obtaining timber for industry. All of this gave rise to increased tension between the traditional agricultural uses and forest administration (Rico, 1995) giving rise to conflicts which could have led to a higher incidence of forest fires.

In fact, the afforestation policy arising from the 1940s has been signalled as the cause of a structural rupture between the forests, intervening from this time with the intention of converting them into exclusively timber-producing spaces, and an agricultural economy with more diverse interests that did not accept the new concept of the territory that the state wished to impose (Seijo, 2009). The conflict arising from this situation has been studied in some depth for the case of Galicia (Rico, 1995; GEPC, 2004; Chas Amil, 2007). In this specific area, tensions intensified at sometimes due to the failure to acknowledge the local ownership of the forests, which was interpreted by the rural population as a dispossession by the State (GEPC, 2004). Some authors have established a direct relationship between the opposition of the local population to the afforestation actions and the forest fires (Cabana, 2007 and 2009), but the relationship should be extended to an unwelcome authoritarian forest policy that could have given rise to fires for different reasons: protests against the imposed uses of the forests, revenge for the complaints of the local population about the use of the space, interests with respect to timber use and interests related to land speculation (Fernández Leiceaga, 1990, Fuentes-Santos, et al, 2013).

This last aspect can be linked to some works which claim that FT is more likely to occur in democracies (Mather, Fairnbairn and Needle, 1999) or in territories where there are good governance systems (Barbier and Tesfaw, 2015). In this sense, the Spanish case seems to be atypical, inasmuch as FT took place within a dictatorial political system. Nevertheless, the postulates of Barbier and Tesfaw (2015) could be used to explain this. On the one hand, dictatorship is not incompatible with the "rule of law" which makes the development of large public works programmes possible, including afforestation. On the other hand however, the dictatorship was a system imposed by force and strongly influenced by the economic interests of the economic elite classes, and this could have resulted in low quality regulations that led to inadequate afforestation programmes with perverse effects. The fact that a relationship between afforestation and 
wildfires has also been detected in Portugal, the other western European country with a long dictatorship in the twentieth century (Oliveira et al, 2017), indicates that the institutional system is a very important factor in FT models and their consequences.

\section{Conclusions}

The evidence provided in this paper shows that Forest Transitions developed in the second half of twentieth century may have had, in some circumstances, unexpected negative effects on the spread of forest fires. In fact, in the case of Spain, a positive and statistically significant relationship exists between forest fires and afforested hectares in the period 1968-2002. This relationship arise if we consider the average afforestation carried out in a period of between 25- 35 years before the occurrence of the fire, that is, a period in which planted masses reach maturity and are near to their felling age. This effect increases when the model is implemented exclusively for the Cantabrian and Atlantic north-west provinces on which afforestation had special importance.

The causality of the perverse effect that FT had in Spain must be found in three complementary aspects of the process. The first is related to the mono-specific plantations and the species chosen to develop afforestation programmes which together, resulted in a high flammability of the woodland created. The second aspect is related to the economic objectives of the afforestation programmes. The economic and industrial powers were interested in planting fast or medium growth species covering large areas, more suitable for increasing timber exploitation or protecting the big water reservoirs built in the same period. In general terms, these economic criteria generated an afforestation programme in which the quantity of trees was much more important than the quality of the forests. It is also possible that the economic interest to control the timber markets could be directly related to the occurrence of fires, although this hypothesis needs to be confirmed with more research. The third complementary aspect is probably the most important and is related to the authoritarian political framework within which the afforestation programmes were developed. The dictatorship imposed far-reaching transformations of many rural spaces without taking into account the people living on the land, resulting in dysfunctions that affected the forest fires.

It is evident that the effects detected in Spain cannot be extended as a rule of FT in other territories. Nevertheless, the Spanish case introduces a possible relationship between FT and forest fires (that has also been suggested for the case of Portugal) that should not be ignored by FTT, especially in those environmental contexts prone to fires. At the same time, the model of FT developed in Spain in a dictatorial context gives some interesting clues for a better understanding of FT developed in authoritarian contexts where there are strong productivist interests at play.

Acknowledgements 
A preliminary version of this article was presented and discussed in the "IV Agricliometrics Conference", held in Cambridge University (Madelaine College) in April 2017. We would like to thank the valuable comments of the attendees. We would also like to thank to Vicente Pinilla, Fran Beltran and Ana Angulo for their comments during the writing of this article and Kate Walters for the English revision of the paper.

Formatting of funding sources

This work has been partially supported by the Ministry of Science and Innovation of the Spanish Government, projects ECO2015-65582, and ECO2016-74940, the Department of Science, Technology and Universities of the Government of Aragon and the European Regional Development Fund (Research Groups "Agrifood Economy, Globalization, Economic Development and Environment (19th - 21st Century)", "Econometric Model selection" and "Growth, Demand and Natural Resources").

\section{References}

Alvarez, P. 2000. Manual de selvicultura de Frondosas Caducifolias. Proyecto agrobyte, 2000. (www.agrobyte.com)

Badía A., Serra P., and Modugno S. 2011. Identifying dynamics of fire ignition probabilities in two representative Mediterranean wildland-urban interface areas. Appl. Geog. 31, 930-940. Doi: 10.1016/j.apgeog.2011.01.016.

Barbier, E.B., Burgess, J.C. 2001. The economics of tropical deforestation. J. Econ. Surv. 15 (3), 413-433. Doi: 10.1111/1467-6419.00144

Barbier, E.B., Burgess, J.C., Grainger, A., 2010. The forest transition: towards a more comprehensive theoretical framework. Land Use Policy 27, 108-118. Doi:10.1016/j.landusepol.2009.09.003

Barbier, E.B. and Tesfaw, A., 2015. Explaining forest transitions: The role of governance. Ecological Economics 119, 252-261. Doi: 10.1016/j.ecolecon.2015.09.010

BBV, 1999. Renta Nacional de España y su distribución provincial: Serie homogénea: años 1955 a 1993 y avances 1994 a 1997. Tomo II, Series por provincias, Bilbao: Fundación BBV.

Breusch, T.S. and Pagan, A.R. 1980. The Lagrange Multiplier test and its applications to model specification in econometrics. Rev. Econ. Stud. 47, 239-253.

Bremer, L.L., Farley, K.A. 2010. Does plantation forestry restore biodiversity or create green deserts? A synthesis of the effects of land-use transitions on plant species richness, Biodivers. Conserv. 19, 3893-3915. Doi: 10.1007/s10531-010-9936-4

Cabana, A. 2009. Incendiarios de las repoblaciones del patrimonio forestal (1940-1975). Algunas notas para su caracterización. Cuad. Soc. Esp. Cienc. For. 30, 203-208. 
Cabana, A. 2007. Los incendios en el monte comunal gallego. Lugo durante el primer franquismo. Historia Agraria 43, 555-557.

Cervera, T., Pino, J., Marull, J., Padró, R., Tello, E. 2016. Understanding the long-term dynamics of forest transition: From deforestation to afforestation in a Mediterranean landscape (Catalonia, 1868-2005), Land Use Policy, in press.

Chas, A.L. 2007a. Forest fires in Galicia (Spain): Threats and challenges for the future. J. For. Econ. 13, 1-5.

Chauvalier, F. 1990. La repoblación forestal en la provincia de Huesca y sus impactos geográficos. Instituto de estudios Altoaragoneses, Huesca.

Culas, R.T. 2012, REDD and forest transition: Tunnelling through the environmental Kuznets curve. Ecological Economics 79, 44-51. Doi:10.1016/j.ecolecon.2012.04.015

FAO, 2007. Fire management global assestment, 2006. FAO Foresty paper 151, 1-122

Fernandez X. 1990. Economía política do monte Galego. Imprenta Universitaria, Santiago de Compostela

Fuentes-Santos, I., Marey-Pérez. M.F. and González-Manteiga, W. 2013. Forest fire spatial pattern analysis in Galicia (NW Spain). J. Environ. Manage. 128, 30- 42. Doi: 10.1016/j.jenvman.2013.04.020.

García Abril A., Yoldi Enríquez I., Canga Cabañes, J.L. 1989. La repoblación forestal, in: Ortega Hernández-Agero, C (ed) El Libro Rojo de los Bosques Españoles. ADENAWWF, Madrid, pp. 237-276.

Gil, L., Prada, M.A. 1993. Los pinos como especies básicas de la restauración forestal en el medio mediterráneo. Ecol. 7, 113-125

Gil, L. 2008. Pinares y Rodenales la Diversidad que no se Ve. Real Academia de Ingeniería, Madrid

Goerlich. F.J. 2012. Datos climáticos históricos para las regiones españolas. CRU TS 2.1. Inv. Hist. Econ., 8, 29-40. Doi: 10.1016/j.ihe.2011.07.001

González de Molina, M., Toledo, V. 2014. The Social Metabolism. A Socio-Ecological Theory of Historical Change. Springer, New York

Gómez Mendoza, J., Mata Olmo, R., 1992. Actuaciones forestales públicas desde 1940. Objetivos, criterios y resultados. Agricultura y Sociedad 65, 15-64. 
Grainger, A., 1995. The forest transition: an alternative approach. Area 27, 242-251.

Greene, W.H. 1997. Econometric Analysis, 3rd ed. Prentice Hall International. Upper Saddle River.

Grupo de Estudio de la Propiedad Comunal, 2004. La devolución de la propiedad vecinal en Galicia (1960-1985). Modos de uso y conflicto de propiedad. Historia Agraria 33, 105-130.

Guijarro, M., Madrigal, J., Hernando, C., Sánchez de Ron, D. and Vázquez de la Cueva, A. 2017. Las repoblaciones y los incendios forestales, in Pemán, J., Iriarte-Goñi, I. and Lario, F. La restauración forestal de España, 75 años de una ilusión, Madrid: MAPAMA-SECF, 343-375.

Heilmayr, R. 2014. Conservation through intensification? The effects of plantations on natural forests, Ecological Economics, 105, 204-210. Doi: 10.1016/j.ecolecon.2014.06.008

IFN1, 1976. Primer Inventario Forestal nacional, España. Ministerio de Medioambiente, Madrid.

IFN2, 1996. Segundo Inventario Forestal Nacional, 1986-1996, España. Ministerio de Medioambiente, Madrid

IFN3, 2006. Tercer Inventario Forestal Nacional, 1997-2000, España. Ministerio de Medio Ambiente, Madrid

Infante, J., Soto, D., Iriarte-Goñi, I., Aguilera, E., Cid, A., Guzmán, G., García-Ruiz, R., y González de Molina, M. 2014. La producción de leña en España y sus implicaciones en la transición energética. Una serie a escala provincial (1900-2000), Working Paper, DT-AEHE, 1416.

Iriarte-Goñi, I. 2013. Forests, fuelwood, pulpwood, and lumber in Spain, 1860-2000: A non-declensionist story. Environmental History, 18(2), 333-359. Doi: 10.1093/envhis/emt002.

Iriarte-Goñi, I. 2017. El contexto socio económico de las repoblaciones en España (1940-c.1980), in Pemán, J., Iriarte-Goñi, I. and Lario, F. La restauración forestal de España, 75 años de una ilusión, Madrid: MAPAMA-SECF, 23-42.

Kauppi, P.E., Ausubel, J.H., Fang, J., Mather, A.S., Sedjo, R.A. and Waggoner, P.E. 2006. Returning forests analyzed with the forest identity. Proceedings of the National Academy of Sciences, 103 (46), 17574-1757. 
Lambin, E.F. and Meyfroidt, P. 2010. Land use transitions: Socio-ecological feedback versus socio-economic change. Land Use Policy 27, 108-118. Doi:10.1016/j.landusepol.2009.09.003

Martínez Ruiz, E. 2013. Lo que la experiencia recomienda en la dirección de la extinción en grandes y peligrosos incendios forestales. WP, Colegio de Ingenieros de Montes. Madrid.

Martínez-Fernández, J., Chuvieco, E., Koutsias N. (2013) Modelling long-term fire occurrence factors in Spain by accounting for local variations with geographically weighted regression. Nat. Hazards Earth Syst. Sci. 13: 311-327. Doi: 10.5194/nhess-13311-2013

Martínez-Fernandez, J., Vega-Garcia, C., Chuvieco, E. 2009. Human-caused wildfire risk rating for prevention planning in Spain. J. Environ. Manage 90, 1241-1252. Doi: 10.1016/j.jenvman.2008.07.005

Mather, A., 1992. The Forest Transition. Area 24, 367-379.

Mather, A.S. and Needle, C.L., 1998. The forest transition: a theoretical basis, Area, 30 (2), 117-124.

Mather, A.S., Fairbairn, J. and Needle, C.L. 1999. The course and drivers of the forest transition: The case of France. J. Rural Studies, 15, 1, 65-90. Doi: 10.1016/S07430167(98)00023-0

Mather, A., 2001. The transition from deforestation to reforestation in Europe. In: Angelsen, A., Kaimowitz, D. (Eds.), Agricultural Technologies and Tropical Deforestation. CABI, Wallingford, UK, pp. 35-52.

Mather, A.S., Pereira, J.M.C., 2006. A transição florestal e o fogo em Portugal. In: Pereira, J.S., Pereira, J.M.C., Rego, F.C., Silva, J.M.N., da Silva, T.P. (Eds.), Incêndios florestais em Portugal: caracterização impactes e prevenção. ISA Press, Lisboa, pp. $257-286$.

Meyfroidt, P., Lambin, E.F., 2011. Global Forest Transition: Prospects for an End to Deforestation. Annual Review of Environment and Resources. 36, 343-71. Doi: 10.1146/annurev-environ-090710-143732

Meyfroidt, P., Lambin, E.F., Erb, K.H. and Hertel, T.H., 2013.Globalization of land use: distant drivers of land change and geographic displacement of land use. Current Opinion in Environmental Sustainability, 5, 438-444.

Montiel Molina, C. 2013 . Investigación geohistórica sobre las causas de los incendios forestales. Montes 114, 17-21 
Nunes A.N. 2012. Regional variability and driving forces behind forest fires in Portugal an overview of the last three decades (1980-2009). Appl. Geog. 34, 576-586. Doi: 10.1016/j.apgeog.2012.03.002

Nunez-Mir, G.C., Iannone III, B.V., Curtis, K., Fei, S. 2015. Evaluating the evolution of forest restoration research in a changing world: a "big literature" review. New Forest, 46, 669-682. Doi: 10.1007/s11056-015-9503-7

Oliveira, T.M., Nuno, G., Oliveira F., Pereira, J.M., Claro, J. 2017. Is Portugal's forest transition going up in smoke? Land Use Policy 66, 214-226. https://doi.org/10.1016/j.landusepol.2017.04.046

Perz, S.G., 2007. Grand theory and context-specificity in the study of forest dynamics: Forest transition theory and other directions. Professional Geographer 59 (1), 105-114. https://doi.org/10.1111/j.1467-9272.2007.00594.xPirard, R., Dal Secco, L., Warman, R. 2016. Do timber plantations contribute to forest conservation? Environmental Science \& Policy 57, 122-130. https://doi.org/10.1016/j.envsci.2015.12.010

Prieto, F. 1989. Incendios forestales. Ideas para una interpretación, in: Ortega Hernández-Agero C (ed) El Libro Rojo de los Bosques Españoles, ADENA-WWF, Madrid, pp. 211-236

Rico, E. 1995. Política forestal e repoblacións en Galicia (1941-1971). Imprenta Universitaria, Santiago de Compostela.

Rico, E. 2008a. Repoblación forestal y sustitución de especies en montes de utilidad pública de la provincia de Soria, 1940-1975. Ager 7, 77-108

Rico, E. 2008b. Las repoblaciones del patrimonio forestal del estado y del ICONA en la provincia de Badajoz, 1941-1977. Historia Agraria 46, 91-124.

Rojas E (1987) Consideraciones sobre repoblación, rentabilidad y propiedad forestal, Montes. Revista de ámbito forestal 14: 22-26

Rudel, T.K., Coomes, O.T., Moran, E., Achard, F., Angelsen, A., Xu, J., Lambin, E., 2005. Forest transitions: towards a global understanding of land use change. Global Environmental Change 15 (1), 23-31.

Seijo, F. 2005. The politics of fire: Spanish forest policy and ritual resistance in Galicia, Spain. Environ. Polit. 4, 380-402. Doi: 10.1080/09644010500087665

Seijo F. 2009. Who framed the forest fire? State framing and peasant counter-framing of anthropogenic forest fires in Spain since 1940. J. Environ. Policy Plan. 11,103-128. Doi: 10.1080/15239080902732570 
SGAM (Subdirección General de Agricultura y Montes), 2012. Estadística General de Incendios Forestales. Ministerio de Agricultura, Alimentación y Medioambiente, Madrid.

Soto, D. 2006. Historia dunha agricultura sustentábel. Transformacións productivas na agricultura galega contemporánea. Santiago de Compostela. Xunta de Galicia.

Tornero, J. 1966. Veinte años de repoblaciones. Montes 127, 3-6.

Vadell, E., De-Miguel, S., Pemán, J. 2016a. Large-scale reforestation and afforestation policy in Spain: A historical review of its underlying ecological, socioeconomic and political dynamics. Land Use Policy 55, 37-48. Doi: 10.1016/j.landusepol.2016.03.017

Vadell, E., De-Miguel, S., Pemán. J. 2016b. Las especies utilizadas en la repoblación forestal realizada en España desde 1877. Distribución, ensayos de introducción y origen del material vegetal. Paper International Conference, Lisbon, ISCTE-IUL, 27-30 January 2016

Vega-García, C., Chuvieco, E. 2006. Applying local measures of spatial heterogeneity to Landsat-TM images for predicting wildfire occurrence in Mediterranean landscapes. Lands. Ecol. 21, 595-605. Doi: 10.1007/s10980-005-4119-5

Vélez, R. 2016. Breve (e incompleta) historia de las aportaciones técnicas de los ingenieros de montes en la lucha contra el fuego de los últimos sesenta años. Montes, $126,28-32$.

Viedma, O., Moity. N., Moreno, J.M. 2015. Changes in landscape fire-hazard during the second half of the $20^{\text {th }}$ century: Agriculture abandonment and the changing role of driving factors Agriculture. Ecosyst. Environ. 207, 126-140. Doi: 10.1016/j.agee.2015.04.011.

Vignote, S., Martíne,z I. 1985. El mercado de la madera en España. Revista de la Asociación de Investigación Técnica de la Madera. (www.infomadera.net)

Vilar, L., Camia, A., San-Miguel-Ayanz, J. and Martín. M.P. 2016. Modeling temporal changes in human-caused wildfires in Mediterranean Europe based on land use-land cover interfaces. For. Ecol. Manage. 378, 68-78. Doi: 10.1016/j.foreco.2016.07.020

Westerling, A.L., Hidalgo,,H.G., Cayan, D., Swetnam, T.W. 2006. Warming and earlier spring increase western U.S. forest wildfire activity. Science 313, 940-943

Wooldridge, J.M. 2002. Econometric Analysis of Cross Section and Panel Data. The MIT Press Cambridge, Massachusetts, London, England. 
Ximénez de Embún, J., Ceballos, L. 1939. Plan General para la Repoblación Forestal de España. In: Organismo Autónomo Parques Nacionales (ed) Tres Trabajos Forestales. Ministerio de Medio Ambiente, Madrid, pp. 431-445.

\footnotetext{
i The increase in Forest Surface covered by trees was compatible with a decrease in Total Forest Surface (including surface covered by scrub, bushes and natural pastures) due to the extension of cultivated land until the seventies. From the eighties on, FT culminated in Spain with the raise of Total Forests Surface until now (Infante et al, 2014, table1, p.10).

ii The coastal provinces included in this group from east to west are: Guipúzcoa, Vizcaya, Cantabria, Asturias, Lugo, Coruña and Pontevedra. The inland provinces are Orense, León and Zamora.

iii The effects that fire can have on timber depend on the exterior protection of the tree bark and the type of fire in each case. In many cases, the tree trunks have retained sufficient quality so as to be of economic use after the fire.
} 